\title{
The Prevalence of Obesity among Women of Reproductive Age in Lagos, Nigeria
}

\author{
Article by Oriakhi Abel Toms \\ Mph Student Texila American University, Nigeria. \\ Email:abeltoms@yahoo.co.uk
}

\section{Introduction}

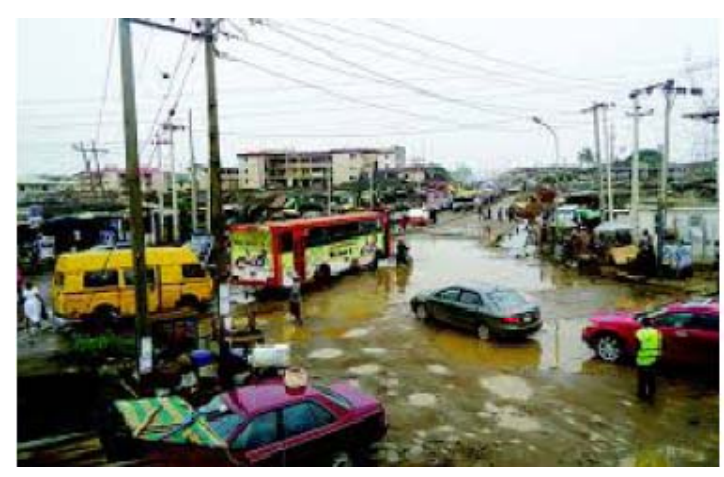

Figure 1: A center of activities in Ejigbo Community

There is a fast emerging "silent killer" in town. It joins the ranks of malnutrition, malaria, hypertension, diabetes, HIV/AIDS, etc. It is obesity!

It has been defined as a condition of abnormal or excessive fat accumulation in adipose tissue, to the extent that health may be impaired.

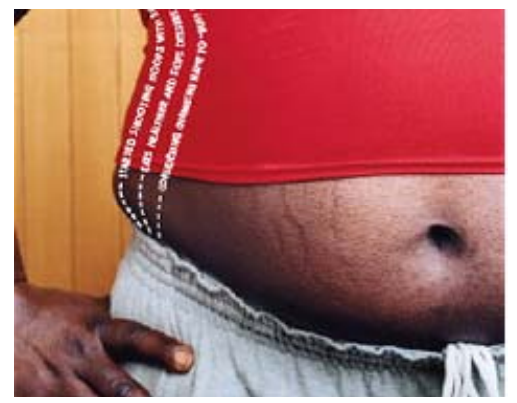

Figure 2: A case of central Adiposity

It is a lifestyle disease characterized by excessive fat accumulation in the tissues. We are eating our way to the grave as obesity and its attendant public health impact stare at us on the face not sparing the developed or developing countries. This does not come as a surprise. Globally, the epidemic is growing. It is a substantial public-health crisis in the developed world, but the prevalence is increasing rapidly in numerous developing nations worldwide

Conservative estimates suggest that as many as 250 million people are obese and about two to three times this number are overweight

Now one of the leading causes of non-communicable chronic diseases, contributing majorly to morbidity and mortality globally with about 3.4 million associated deaths annually.

Obesity is implicated in about $44 \%$ cases of Diabetes mellitus, 23\% Ischemic heart disease and about $41 \%$ of cancer cases.

It is a product of interplay among psycho-social, genetic and environmental factors, resulting from an imbalance between calorie intake and expenditures.

In Nigeria, there are many socio-cultural practices that encourage the fast ascendancy of obesity prevalence especially among women. Among the Ibibios, there is a place called the Fattening room-where a bride is kept for some weeks prior to the wedding event. She will be 
fed for this period with fattening food substances to bring out all her curves for more sexual allures. In black Africa generally, being slim and streamlined in a woman is reproachful not desirable by men.

When woman is getting married, she is made to understand that her wardrobe must change, and this is why the grooms are compelled to buy her a box of new outfits-outfits made for a married woman, that is; wrappers and blouses. The wrappers are to rest very well on a well robust and plumbwaist. Even among the male counterparts, central adiposity as seen in pot bellies is a symbol of pride, manhood, good When a woman is in purdah, she is not allowed to go out for any physical activity but she is allowed to eat, which paints a perfect picture of a sedentary life style that engenders obesity.

When a woman puts to bed in this part the world, many people especially relatives rally round her for support and she is ultimately prevented from getting involved in any physical activities. Special dishes are prepared for her, and these together prevents her from losing the weight gained during pregnancy.

Medically speaking, obesity and overweight are never favorable factors in the overall management of a patient, from the point of examination to the point of investigation and treatment.

As a sonologist for some years, I have experienced so many areas of difficulties in scanning obese patients- with all the adjustments of the table and scanning frequencies; it is always challenging to make accurate diagnosis in such patients.

Nigeria is a place where the services of nutritionists are least recommended and regarded, everybody eats what he or she likes irrespective of what it has to contribute to the body. And this gives obesity the root it has acquired in Nigeria.

\section{Statement of the problem:}

Studies have shown that obesity is on the increase worldwide not sparing the Nigerian people. Its prevalence is almost double what obtained in $1980.65 \%$ of the world's population live in countries where obesity related diseases kill more people than underweight.

In developing countries like Nigeria, 115 million people suffer from obesity related problems with higher rate of obesity occurring among women.

To the Gynecologist, obesity contributes a lot to so many reproductive health outcomes like: An ovulation, menstrual irregularities, polycystic ovarian syndrome and spontaneous abortions.

The Obstetrician is not left out without a share of the negative health challenges posed by obesity. Examples are: Pregnancy induced Hypertension, Gestational diabetes, Thromboembolism, Urinary track infection, Induction of labor, Instrumental deliveries, Caesarean, Anesthetic complications and postoperative complications. There can also be neural tube, congenital heart disease and fetal macrosomia on the side of the fetus.

Obesity in Nigeria having a strong socio-cultural undertone, needs more to be done for its mitigation.

Nigeria is a place where multiparity reigns and from studies, a woman gains at least $1 \mathrm{~kg}$ from each pregnancy-this is why this study is focusing on women of reproductive age so as to evaluate the impact our sociocultural practices on the prevalence of obesity in a Nigerian community and for appropriate recommendations to be made.

\section{Justification for the study:}

With the fast growing prevalence rate of obesity in Nigeria, with due consideration of the contribution made by overweight and obesity to the morbidity and mortality pattern in the part of the world, it is clear enough that obesity is now fast constituting a public health threat which has to be looked into critically before it becomes overwhelming.

\section{Aims and objectives:}

\section{General Objective:}


To assess the prevalence of Obesity in women of child bearing age in Ejigbo Community of Lagos State.

Specific Objectives:

- To relate the social status subjects to the prevalence of obesity.

- To evaluate the effect parity to the prevalence of obesity among subjects.

- To evaluate the relationship between subjects occupation and the prevalence of obesity.

- To reveal the relationship between Dietary preferences of subjects and the prevalence of obesity.

- To evaluate the effect of age on obesity among subjects.

- To evaluate the effect of exercise on occurrence of obesity among subjects.

\section{Literature review}

Obesity is a major public health challenge especially in adult women of child bearing age. From 1988 to 1994, 22\% of non pregnant women from 18 years to 49 years were overweight and another 22\% obese in the United States. Obesity increases the risk of chronic diseases, mortality, infertility and adverse pregnancy outcomes in the population under focus. Overweight and obesity are leading risks for global deaths from noncommunicable diseases. Research has it that about $17 \%$ of the world's population are obese and in developing countries, it is estimated that over 115 million people suffer from obesity-related problems.

According to Aldair[2005], the prevalence of obesity in Morocco is $40 \%$. In South Africa, half of the women population are obese.

Our neighboring Ghanaian town called Accra recorded a prevalence of 37.1\%.

In Nigeria, several researches have been done in this area. One done in south western Nigeria at Ibadan, prevalence of $41.8 \%$ was the prevalence rate among women of reproductive age.

A study done at Uyo in south southern Nigeria recently, a a prevalence of $62.6 \%$ was gotten among female Nurses with a mean BMI of $35.15 \mathrm{~kg} / \mathrm{m} 2$.

In this study, the prevalence in Lagos will be ascertained.

\section{Materials and methods}

Ejigbo is a suburb in Lagos city of about 100000 people. A component part of Oshodi-Isolo Local Government Area. The population is a blend of all the social classes.

Body Mass Index is an indirect method of measuring obesity which this project intends to adopt. It is defined as weight divided by height squared [ $\mathrm{Kg} / \mathrm{m} 2]$.

Below 15 is starvation, 15 to 18 is underweight, 19 to 24.9 is normal weight, 25 to 29.9 is overweight and above 30 is obesity.

Study Duration: Ten Days between 10th of November 2014 to 19th of November;2014.

Sample size: Total number of women of reproductive age that visited outpatient department in a major health center in Ejigbo community of Lagos state in mid November [10th Nov 2014- 19th Nov 2014], which amounted to 81 clients.

Method of Data collection: Collected directly from the Out Patient Department of a private Medical center in Ejigbo community.

Method of Data Analysis: Data will be analyzed using IBM SPSS version 20.0. Level of significance taken to be 0.05 by estimating power to be $95 \%$. Data will be presented through frequency tables, cross tables and a chart.

Levels of statistical significance will be ascertained through chi-square use.

Ethical consideration: Conditions stated in the Helsinki Declaration of 2013 regarding human nonexperimental studies are being strictly adhered to.

Names of subjects are also not mentioned for confidentiality purpose.

Limitations of Study: It includes errors arising from sampling method and data analysis.

\section{Results}


South American Journal of Public Health

Special Edition May 2016

Frequency Tables:

Fig: 1 EDUCATION

\begin{tabular}{|l|l|l|l|l|l|}
\hline & & Frequency & Percent & Valid Percent & Cumulative Percent \\
\hline \multirow{5}{*}{ Valid } & PRIMARY & 20 & 24.7 & 24.7 & 24.7 \\
& SECONDARY & 37 & 45.7 & 45.7 & 70.4 \\
& TERTIARY & 24 & 29.6 & 29.6 & 100.0 \\
& Total & 81 & 100.0 & 100.0 & \\
\hline
\end{tabular}

Fig: 2 PARITY

\begin{tabular}{|l|l|l|l|l|l|}
\hline & & Frequency & Percent & Valid Percent & Cumulative Percent \\
\hline \multirow{5}{*}{ Valid } & P & 1 & 1.2 & 1.2 & 1.2 \\
& MULTIPAROUS & 27 & 33.3 & 33.3 & 34.6 \\
& NULLIPAROUS & 26 & 32.1 & 32.1 & 66.7 \\
& PRIMIPAROUS & 27 & 33.3 & 33.3 & 100.0 \\
& Total & 81 & 100.0 & 100.0 & \\
\hline
\end{tabular}

Fig: 3 DIET

\begin{tabular}{|l|l|l|l|l|l|}
\hline & & Frequency & Percent & Valid Percent & Cumulative Percent \\
\hline \multirow{5}{*}{ Valid } & BOTH & 23 & 28.4 & 28.4 & 28.4 \\
& EATRY & 28 & 34.6 & 34.6 & 63.0 \\
& HOME & 30 & 37.0 & 37.0 & 100.0 \\
& Total & 81 & 100.0 & 100.0 & \\
\hline
\end{tabular}

Fig: 4 EXERCISE

\begin{tabular}{|l|l|l|l|l|l|}
\hline & & Frequency & Percent & Valid Percent & Cumulative Percent \\
\hline \multirow{4}{*}{ Valid } & NO & 44 & 54.3 & 54.3 & 54.3 \\
& YES & 37 & 45.7 & 45.7 & 100.0 \\
& Total & 81 & 100.0 & 100.0 & \\
\hline
\end{tabular}

Fig: 5 OBESITY

\begin{tabular}{|l|l|l|l|l|l|}
\hline & & Frequency & Percent & Valid Percent & Cumulative Percent \\
\hline \multirow{4}{*}{ Valid } & NOT OBESE & 51 & 63.0 & 63.0 & 63.0 \\
& OBESE & 30 & 37.0 & 37.0 & 100.0 \\
& Total & 81 & 100.0 & 100.0 & \\
\hline
\end{tabular}

\section{Cross Tables:}

Fig: 6 AGE VS OBESITY ( $\mathrm{P}>0.05]$

\begin{tabular}{|r|c|c|c|}
\hline & \multicolumn{2}{|c|}{ OBESITY } & \multirow{2}{*}{ Total } \\
\cline { 2 - 4 } & NOT OBESE & OBESE & \\
\hline 16.00 & 1 & 0 & 1 \\
17.00 & 2 & 0 & 2 \\
22.00 & 0 & 1 & 1 \\
24.00 & 0 & 1 & 1 \\
& & &
\end{tabular}




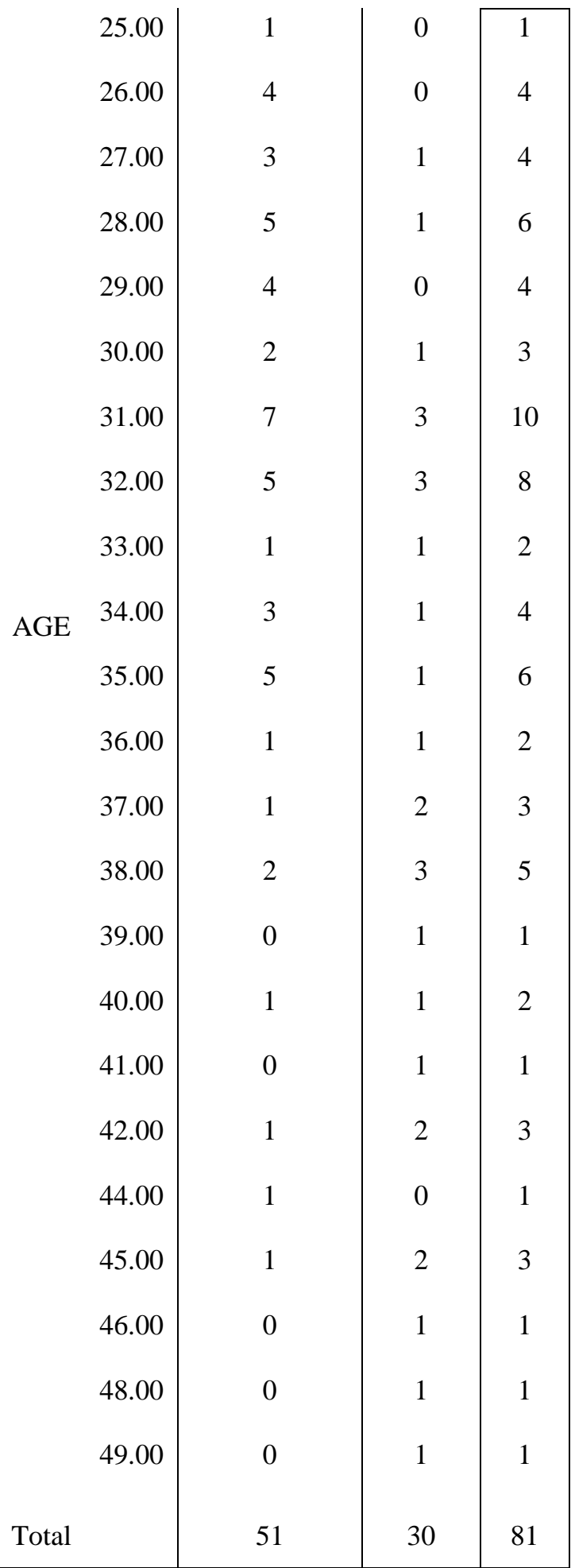

$\mathrm{P}>0.05$ :There is no statistical significant relationship between Age and Obesity in this study.

Fig: 7 EDUCATION * OBESITY Crosstabulation

\begin{tabular}{|l|l|c|c|c|}
\hline \multicolumn{2}{|c|}{} & \multicolumn{2}{|c|}{ OBESITY } & \multirow{2}{*}{ Total } \\
\cline { 3 - 4 } \multicolumn{2}{|c|}{} & NOT OBESE & OBESE & \\
\hline \multirow{2}{*}{ EDUCATION } & PRIMARY & 16 & 4 & 20 \\
& SECONDARY & 28 & 9 & 37
\end{tabular}


South American Journal of Public Health

Special Edition May 2016

\begin{tabular}{|l|l|l|l|l|} 
& TERTIARY & 7 & 17 & 24 \\
Total & & 51 & 30 & 81 \\
\hline
\end{tabular}

$\mathrm{P}<0.05$ : There is a statistically significant relationship between Education and Obesity.

Fig: 8 PARITY * OBESITY Crosstabulation

\begin{tabular}{|l|l|c|c|c|}
\hline \multicolumn{2}{|c|}{} & \multicolumn{2}{|c|}{ OBESITY } & \multirow{2}{*}{ Total } \\
\cline { 3 - 4 } \multicolumn{2}{|c|}{} & NOT OBESE & OBESE & \\
\hline \multirow{4}{*}{ EDUCATION } & P & 0 & 1 & 1 \\
& MULTIPAROUS & 9 & 18 & 27 \\
& NULLIPAROUS & 23 & 3 & 26 \\
Total & PRIMIPAROUS & 19 & 8 & 27 \\
& & 51 & 30 & 81 \\
\hline
\end{tabular}

$\mathrm{P}<0.05$ : The relationship between Parity and Obesity is statistically significant

Fig: 9 DIET * OBESITY Crosstabulation

\begin{tabular}{|c|c|c|c|c|}
\hline \multicolumn{2}{|c|}{} & \multicolumn{2}{|c|}{ OBESITY } & \multirow{2}{*}{ Total } \\
\cline { 3 - 4 } \multicolumn{2}{|c|}{} & NOT OBESE & OBESE & \\
\hline \multirow{5}{*}{ Total } & BOTH & 17 & 6 & 23 \\
& EATRY & 14 & 14 & 28 \\
& HOME & 20 & 10 & 30 \\
& 51 & 30 & 81 \\
\hline
\end{tabular}

P>0.05: Dietary preferences and Obesity are not statistically related significantly.

Fig: 10 EXERCISE * OBESITY Crosstabulation

\begin{tabular}{|l|l|ll|l|l|}
\hline \multicolumn{2}{|c|}{} & \multicolumn{3}{|c|}{ OBESITY } & Total \\
\cline { 3 - 5 } \multicolumn{2}{|c|}{} & NOT OBESE & OBESE & \\
\hline EDUCATION & NO & 23 & & 21 & 44 \\
Total & YES & 28 & & 9 & 37 \\
& & & 51 & 30 & 81 \\
\hline
\end{tabular}

$P<0.05$ : There is a statistically significant relationship between Exercise and Obesity. www.obesidade.info/estudos/obesity.pdf)

\section{Discussion}

This research has thrown more light on the distribution of a Lagos community of Nigeria. Although there is a very high level of agreement between factors considered in this research as relating to the prevalence of obesity and already established ones, this research has proven to be unique in the sense that the level of influence these factors have vary with what obtains somewhere else.

Among the respondents, this research has shown that $45.7 \%$ of our subjects have secondary level of education while about $29.6 \%$ schooled up to the tertiary level. Primary level of education is $24.7 \%$. This is typical of a community dominated by poor to average income earners. Further statistical analysis shows that there is a significant relationship between the level of education and obesity as $56.7 \%$ of obese subjects educated to the tertiary level. About $30 \%$ are of secondary educational qualification and only $13 \%$ of subjects stopped at the primary school level. This implies that the higher ones level of education if in the group of women of reproductive age, the higher the chances of obesity. This is so, because in Nigeria, one's socio-economic status is a reflection of one's level of education. The class with tertiary level of education get involved more in office jobs which encourages sedentary. They also patronize fast food centers because they have the where withal to do so, as against subjects of low socio-economic class who prepare their food locally at home.

Another factor that was considered was parity. This study has shown that among women of reproductive age in Ejigbo community, Multiparity is statistically related positively to the 
occurrence of obesity. Up to $66.7 \%$ of multiparous subjects are obese while only $11.5 \%$ of the Nulliparous subjects are obese. In between these extreme groups are the primiparous subjects with $29.6 \%$ obesity prevalence. This agrees with international research conclusion that multiparity increases the prevalence of obesity.

This research has shown that age has no significant statistical relationship with the prevalence of obesity in Ejigbo community of Lagos Mainland though majority of multiparous respondents are of older reproductive age. This is however contrary to the popular scientific fact the tissue adiposity increases with age.

Dietary preferences by dint of this research has proven not to be statistically related to the prevalence of obesity in the study population, although, 50\% of subjects that get their food source from eatery centers are obese among subjects. The least impact of diet is seen among subjects getting their food source from both home and eatery.

From this study, it is shown that exercise has inverse relationship with occurrence of obesity. Ninety one percent of subjects not involved in exercise are obese confirming that obesity results from inactivity.

\section{Conclusions}

This research has shown that the people of Lagos state of Nigeria are not spared from the this obesity epidemic. It is more associated with people of high social class, people of high parity level , inactive people and the well educated.

In a system that prides on multiparity and grand-multiparity where one's position at the village meeting is predicated on the number of children he has birthed, in a system where pot-bellied ones are regarded as healthy men and women, in a community where lean individuals are seen as people not having enough to eat, in a system where engaging in routine physical exercise is seen as an act of joblessness and irresponsility, in a system where awareness level about obesity is very low, what then can be done in such a system to tame the fast growing rate of obesity?

\section{Recommendations:}

- Government should take the lead in this campaign against this obesity epidemic

- Adequate health promotion programs to be carried out by all the stake holders at all levels

- Government should take a bold step in confronting all negative sociocultural practices that exist in Nigeria.

- Religious leaders should be informed by way of health education about obesity.

- Traditional rulers and all other stake holders should be conscripted into fight against the obesity epidemic.

- Recreational centers should be encouraged in office environments

- Family planning should be taught and strictly enforced.

- Government should make laws to regulate multiparity and grandmultiparity.

- Nutritional medicine should be developed in Nigeria.

- NAFDAC [Nigeria Food and Drug Administration and Control] should regular more strictly all the eatery centers.

\section{References:}

[1.] African journal of reproductive health( 2013 ]

[2.] Global health observatory

[3.] obesity in adult Nigerians

[4.] Socio-demographic correlates of overweight and obesity among women of reproductive age-2008( Matthew Okoh\}

[5.] Prevalence of obesity among women attending a Nigerian primary care clinic( Ibadan]

[6.] Prevalence of overweight and and obesity and perception of healthy and desirable body size in urban Ghana. 
South American Journal of Public Health Special Edition May 2016

[7.] Tropical journal of health sciences.

[8.] www.academicjournal.org

[9.] www.vanguardngr.com

[10.] www.nigeriamedj.com

[11.] www.njcponline.com

[12.] www.knoema.com

[13.] www.obesidade.info/estudos/obesity 